University of Nebraska - Lincoln

DigitalCommons@University of Nebraska - Lincoln

USDA National Wildlife Research Center - Staff Publications
U.S. Department of Agriculture: Animal and Plant Health Inspection Service

2009

\title{
Wildlife collisions with aircraft: A missing component of land-use planning for airports
}

\author{
Bradley F. Blackwell \\ USDA-APHIS-Wildlife Services, bradley.f.blackwell@aphis.usda.gov \\ Travis L. DeVault \\ USDA/APHIS/WS National Wildlife Research Center, Travis.L.DeVault@aphis.usda.gov \\ Esteban Fernández-Juricic \\ Purdue University, Department of Biological Sciences \\ Richard A. Dolbeer \\ Huron, $\mathrm{OH}$
}

Follow this and additional works at: https://digitalcommons.unl.edu/icwdm_usdanwrc

Part of the Environmental Sciences Commons

Blackwell, Bradley F.; DeVault, Travis L.; Fernández-Juricic, Esteban; and Dolbeer, Richard A., "Wildlife collisions with aircraft: A missing component of land-use planning for airports" (2009). USDA National Wildlife Research Center - Staff Publications. 860.

https://digitalcommons.unl.edu/icwdm_usdanwrc/860

This Article is brought to you for free and open access by the U.S. Department of Agriculture: Animal and Plant Health Inspection Service at DigitalCommons@University of Nebraska - Lincoln. It has been accepted for inclusion in USDA National Wildlife Research Center - Staff Publications by an authorized administrator of DigitalCommons@University of Nebraska - Lincoln. 


\title{
Review
}

\section{Wildlife collisions with aircraft: A missing component of land-use planning for airports}

\author{
Bradley F. Blackwell ${ }^{\mathrm{a}, *}$, Travis L. DeVault ${ }^{\mathrm{a}}$, Esteban Fernández-Juricic ${ }^{\mathrm{b}}$, \\ Richard A. Dolbeer ${ }^{\mathrm{c}}$ \\ a United States Department of Agriculture, Animal and Plant Health Inspection Service, Wildlife Services, National Wildlife Research Center, \\ Ohio Field Station, 6100 Columbus Avenue, Sandusky, OH 44870, USA \\ b Purdue University, Department of Biological Sciences, 915 W. State Street, West Lafayette, IN 47907-2054, USA \\ c 1228 Laguna Drive, Huron, $\mathrm{OH} 44839$, USA
}

\section{A R T I C L E I N F O}

\section{Article history:}

Received 28 January 2009

Received in revised form 28 May 2009

Accepted 6 July 2009

Available online 7 August 2009

\section{Keywords:}

Airport planning

Aviation hazard

Bird strike

Land use

Risk

Wildlife strike

\begin{abstract}
A B S T R A C T
Projecting risks posed to aviation safety by wildlife populations is often overlooked in airport land-use planning. However, the growing dependency on civil aviation for global commerce can require increases in capacity at airports which affect land use, wildlife populations, and perspectives on aviation safety. Our objectives were to (1) review legislation that affects airports and surrounding communities relative to managing and reducing wildlife hazards to aviation; (2) identify information gaps and future research needs relative to regulated land uses on and near airports, and the effects on wildlife populations; and (3) demonstrate how information regarding wildlife responses to land-use practices can be incorporated into wildlife-strike risk assessments. We show that guidelines for land-use practices on and near airports with regard to wildlife hazards to aviation can be vague, conflicting, and scientifically ill-supported. We discuss research needs with regard to management of stormwater runoff; wildlife use of agricultural crops and tillage regimens relative to revenue and safety; the role of an airport in the landscape matrix with regard to its effects on wildlife species richness and abundance; and spatial and temporal requirements of wildlife species that use airports, relative to implementing current and novel management techniques. We also encourage the development and maintenance of datasets that will allow realistic assessment of wildlife-strike risk relative to current airport conditions and anticipated changes to capacity. Land uses at airports influence wildlife populations, and understanding and incorporating these effects into planning will reduce risks posed to both aviation safety and wildlife species.
\end{abstract}

Published by Elsevier B.V.

\section{Contents}

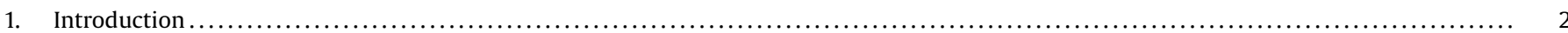

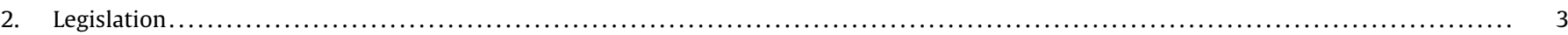

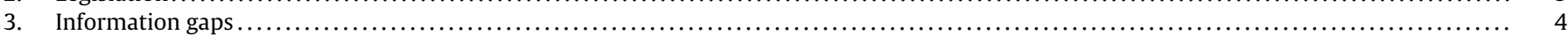

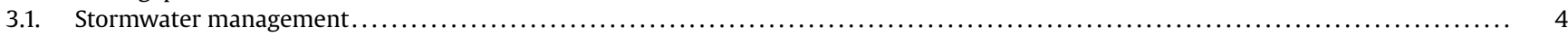

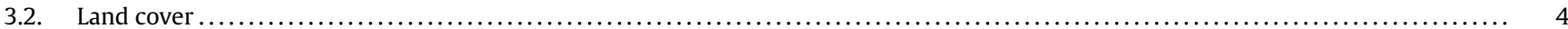

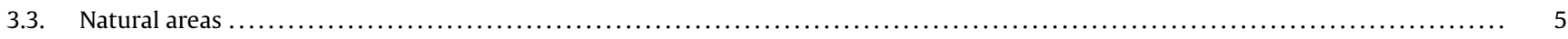

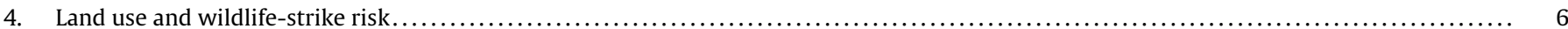

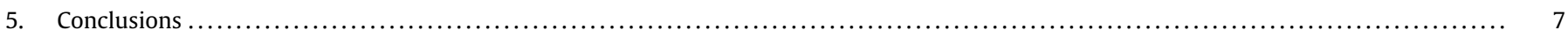

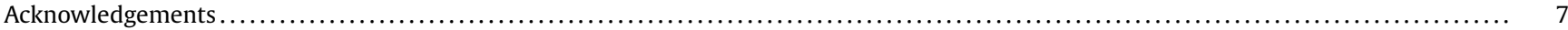

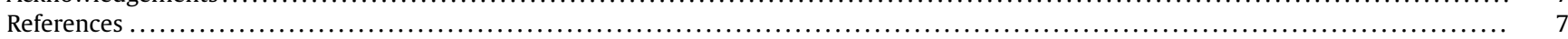

* Corresponding author. Tel.: +1 419625 0242; fax: +1 4196258465 .

E-mail address: Bradley.f.blackwell@aphis.usda.gov (B.F. Blackwell). 


\section{Introduction}

Safety and revenue are critical factors to the ability of civil aviation to meet the demands of global commerce. However, aircraft collisions with birds and other wildlife (wildlife strikes) pose an increasing safety and financial threat to the civil aviation industry worldwide (Allan, 2002; Dolbeer and Eschenfelder, 2002; Dolbeer and Wright, 2008). The estimated cost (direct and indirect expenses) to civil aviation worldwide is over U.S. \$1.2 billion annually (Allan, 2002). Wildlife strikes have claimed over 219 lives and over 200 aircraft (military and civil) since 1988 (Richardson and West, 2000; Thorpe, 2003, 2005; Dolbeer and Wright, 2008). In the USA, 82,057 wildlife strikes (97.5\% involving birds) were reported to the Federal Aviation Administration (FAA; 1990-2007) and represent at least U.S. $\$ 628$ million annually in direct and indirect losses (Dolbeer and Wright, 2008). Importantly, these wildlifestrike statistics reflect an increasing risk (i.e., likelihood of harm) to aviation safety (Dolbeer, 2006a).

Air traffic has increased markedly with the post-World War II advent and growth of the civil aviation industry (Kelly and Allan, 2006). By the 1960s, airframes were larger and turbine power was replacing piston-powered engines. Both trends contributed to a higher likelihood of wildlife strikes, because the greater surface area of an aircraft and the vacuum associated with jet engines represent a larger area to avoid for any animal in the flight path (Solman, 1973). Further, there is a greater probability for jet engines, versus piston-powered engines, to suffer damage upon ingestion of an animal (Solman, 1973). Also, air carriers recently have replaced four-engine aircraft with two-engine designs that markedly reduce the noise of their predecessors, which is suspected to reduce the distance at which animals can detect and react to aircraft (Solman, 1976; Kelly et al., 2001; Kelly and Allan, 2006). Another factor contributing to the observed increase in bird strikes is population growth of some species (e.g., Rusch et al., 1995; Waller and Alverson, 1997; Blackwell et al., 2007), especially larger animals ( $>2 \mathrm{~kg}$ ) that present substantial hazards to aviation safety (Dolbeer et al., 2000; Dolbeer and Eschenfelder, 2002; Dolbeer and Wright, 2008).

Analysis of strike data indicates that habitat management on and near airports plays a significant role in the frequency of wildlife strikes (Cleary and Dolbeer, 2005; DeVault et al., 2005; Blackwell and Wright, 2006; Dolbeer, 2006b). Specifically, wildlife (particularly birds) use of habitats within approach and departure zones increases the likelihood of wildlife strikes because of the altitudes in which aircraft operate within those areas. For example, Dolbeer (2006b) found that $95 \%$ of bird strikes reported to the FAA (1990-2004) occurred at <1067 $\mathrm{m}$ above ground level (AGL), altitudes for which aircraft on approach and departure would be within $18.5 \mathrm{~km}$ of major airports (those that serve at least 5 million passengers annually; FAA, 2008a). For strikes $>152$ m AGL, waterfowl (Anatidae), gulls/terns, passerines, and vultures were the species groups most frequently struck. Song-birds (Passerines), gulls/terns (Laridae), doves (Columbidae), and raptors (including vultures) were the species groups most frequently struck at altitudes $\leq 152 \mathrm{~m}$ AGL. Notably, for strikes resulting in substantial damage to the aircraft (Dolbeer et al., 2000; Dolbeer and Wright, 2008), 66\% occurred at $\leq 152 \mathrm{~m}$ AGL (Dolbeer, 2006b). In general, an aircraft descending on a $3^{\circ}$ glideslope would be $\leq 152 \mathrm{~m}$ AGL at $3 \mathrm{~km}$ from the runway (Flight Safety Foundation, 2000).

Therefore, measures to reduce wildlife hazards to aviation on airport property can be augmented by land-use management involving municipalities in surrounding areas (Rao and Pinos, 1998; Sodhi, 2002). Such collaboration is more pressing now with the anticipated demands on airports both for revenue and capacity (the maximum number of flights that an airport can routinely accept per hour). For example, to accommodate demands for airport development and growth (e.g., runway designs for larger aircraft, as well as new gate, taxiway, and apron configurations) worldwide through 2010, Humphreys et al. (2001) estimated a cost at U.S. $\$ 350$ billion. By 2017, the FAA anticipates a $45 \%$ increase in passengers accompanied by a $33 \%$ increase in air carrier operations (FAA, 2008b). Through 2025, the U.S. civil fleet is anticipated to grow by $2.5 \%$ annually to accommodate increased demand, with the narrow-body fleet (i.e., aircraft with fuselage diameter from 3-4 $\mathrm{m}$ ) projected to grow by 117 aircraft annually; the wide-body fleet (fuselage diameter $\geq 5 \mathrm{~m}$ ) is projected to grow by 40 aircraft annually as the Boeing 787 and Airbus A350s enter existing fleets (FAA, 2008b). This increase in air carrier operations and aircraft size at the busiest airports will warrant development of additional runways to increase capacity. Globally, 9 billion passengers are expected by 2025, and the number of annual aircraft movements anticipated is 120 million (Aaronson, 2007). Planning for increasing airport capacity includes not only infrastructure, but potential economic linkages with surrounding communities, flight safety, and environmental concerns (Kelly and Allan, 2006).

For example, Graham and Guyer (1999), referring to projected growth of air transport within the European Union, suggested that planners must consider environmental capacity, which comprises infrastructure, sources of pollution, and visual amenity. Similarly, Abeyratne (2000) argued that effective expansion and management of airport capacity includes environmentally sustainable development (as outlined in the Rio Declaration on Environment and Development, United Nations Conference on Environment and Development). Vreeker et al. (2002) developed an evaluation process for airport expansion planning that includes safety (defined as a qualitative factor) and environment considerations, such as natural conservation areas and anticipated disturbance of fauna habitats. Lee and Yang (2003) examined strategies that would enable the incremental development of a "winged city", thus advocating the commercial linkage of an airport to off-airport enterprises (see also Reiss, 2007). The establishment of these economic linkages between an airport and community could prove critical to national economies, particularly given the current global economic downturn (e.g., Butterworth, 2008; Weikel, 2008; Airport Technology, 2009). We note, also, that planning for airport capacity changes is affected by regional perspectives that are separate from economic concerns. For example, environmental considerations figure prominently in the urban planning process in Europe (see European Union, EU, 2001) and could easily run counter to opinions favoring an increase to an airport's capacity. However, notably absent from much of the commentary on airport planning considerations, even work specifying safety and environmental concerns, is guidance on land use to minimize wildlife strikes (e.g., Abeyratne, 2000; but see Khalafalla and El-Rayes, 2006).

A wildlife perspective in airport planning is important because it can influence aviation safety (e.g., Kelly and Allan, 2006). In this study, we (1) review legislation that affects airports and surrounding communities relative to managing and reducing wildlife hazards to aviation; (2) identify information gaps and future research needs relative to regulated land uses on and near airports, and the effects on wildlife populations; and (3) demonstrate how information regarding wildlife responses to land-use practices can be incorporated into wildlife-strike risk assessments. We focus primarily on aviation in the USA, particularly in our reference to the FAA National Wildlife Strike Database as a basis for the development of the risk assessment. Our ultimate purpose is to stimulate collaborative efforts to more accurately assess how changes in capacity needs, considerations for revenue-producing land uses, and goals for resource sustainability on airport properties can affect wildlife hazards and, subsequently, risk posed to aviation safety. Our approach offers an exciting opportunity to integrate different disciplines (wildlife management, landscape ecology, con- 
servation biology, geography, and sensory ecology) into the airport planning process.

\section{Legislation}

The primary body providing oversight and guidance to the civil aviation industry on a worldwide basis is the International Civil Aviation Organization (ICAO). The ICAO is a United Nations Specialized Agency whose mission is to achieve safe, secure, and sustainable development of civil aviation through cooperation among its 190 member states. In 1990, the member states of ICAO adopted, in Annex 14 to the Convention on Civil International Aviation, the following practices regarding bird hazards to aviation: (1) assess the extent of the risk posed by birds on and in the vicinity of airports; (2) take necessary action to decrease the number of birds; and (3) eliminate or prevent the establishment of any site in the vicinity of the airport which might serve as an attraction to birds and thereby present a danger to aviation. Member states voted to make these recommended practices into ICAO Standards, effective November 2003. This action makes these practices a mandatory component of the operation standards at airports within those member states (see Kelly and Allan, 2006; Dolbeer, 2007).

The guidance provided by the ICAO relative to wildlife hazards to aviation safety is found in the Airport Services Manual (ICAO, 1991) and the Airport Planning Manual (ICAO, 2002). Guidance on environmental management and modifications to airport property is found in the Airport Planning Manual and pertains broadly to modifications that might offer food, water, or shelter to wildlife, and primarily birds. Land uses considered as contributing to wildlife hazards on or near (i.e., within $13 \mathrm{~km}$ ) airports are fish-processing operations; agriculture; livestock feed lots; refuse dumps and landfills; factory roofs; parking lots; theaters and food outlets; wildlife refuges; artificial and natural lakes; golf and polo courses, etc.; animal farms; and slaughter houses. In addition, the ICAO grades land uses as to whether they are acceptable within radii from the airport center of 3 and $8 \mathrm{~km}$ (ICAO, 2002). However, by changing from broad guidance to more specific instructions for land uses near airports, and without discussion of potential implications, some ICAO recommendations can be conflicting or misleading. Food-waste disposal, for example, is discouraged within both the 3- and 8-km zones, but non-food garbage is permissible within each zone. However, traditional landfills are generally not food-free and, subsequently, require netting or other management to reduce use by birds. Also, the guidelines recommend that "grass" areas on airports be maintained at $20 \mathrm{~cm}$ or more because "birds do not have good visibility and feeding is hindered" (ICAO, 1991). Such specific guidance, particularly to member states that span bioclimatic and geographic zones, ignores the myriad of factors that might contribute to avian use of grasslands. We suggest, therefore, that contact information be provided for member states that have active wildlife management programs at their airports, including grassland-management protocols. Further, if these management protocols are based on research examining avian foraging and antipredation behaviors in managed grasslands, appropriate references should be included in the ICAO guidelines.

Clearly, the necessity of some land uses at airports, such as parking lots, requires consistent management to deter use by loafing birds. However, other land uses within the ICAO 13-km siting criterion offer opportunities to increase revenue for the airport or other property owners without increasing attraction to wildlife. For example, land not used for airport operations is often leased for agricultural production to generate revenue and minimize maintenance (e.g., mowing costs; ICAO, 1991, 2002). The need to understand which land-cover types might attract hazardous birds is noted. But, there is also opportunity for the ICAO to lead in the dissemination of information or discussion among its member states (e.g., via the web) regarding the use of land covers to reduce use by hazardous wildlife while realizing revenue opportunities or conservation objectives (see Kelly and Allan, 2006).

For airports in the USA, the FAA exerts regulatory control over certification and operation via Title 14 Code of Federal Regulations (CFR), Federal Aviation Regulations, Part 139-Certification of Airports. In general, certificated airports are those facilities that receive scheduled passenger-carrying operations with $>9$ seats or unscheduled passenger-carrying operations with $>30$ seats (CFR $§ 139.1$ ). Currently, there are approximately 570 airports certificated under Part 139. In addition, there are about 2860 non-certificated airports that are organized under the National Plan of Integrated Airport Systems (NPIAS; FAA, 2006). These NPIAS airports are eligible to receive FAA funding under the Airport Improvement Program and, therefore, are encouraged to observe regulations in CFR Part 139.

Regulations concerning wildlife hazards to aviation are found in CFR 139. §139.337-Wildlife Hazard Management. These regulations state that each certificate holder must take immediate action to alleviate wildlife hazards whenever they are detected and ensure that a wildlife hazard assessment (see Cleary and Dolbeer, 2005) is conducted when any of the following events occur on or near the airport: (1) an air carrier experiences multiple wildlife strikes (a strike might involve multiple birds; see also 4, below); (2) an air carrier experiences substantial damage (damage or structural failure adversely affecting strength, performance, or flight) from striking wildlife; (3) an air carrier experiences engine ingestions of wildlife; or (4) wildlife of a size, or in numbers, capable of causing a strike (as defined above) is observed to have access to any airport flight pattern or aircraft movement area. Further, the wildlife hazard assessment must contain at least the following: (1) analysis of events or circumstances that prompted assessment; (2) identification of wildlife species observed, numbers, locations, movements, and daily and seasonal occurrences; (3) identification and location of features on and near the airport that attract wildlife; (4) a description of wildlife hazards to air carrier operations; and (5) recommended actions for reducing identified wildlife hazards to air carrier operations. However, because wildlife populations on and near airports are not static, but change in response to local land use, management policies (including control strategies), season, and climatic conditions (Cleary and Dolbeer, 2005), the FAA provides additional guidance to both certificated and non-certificated airports via the Advisory Circular (AC) 150/5200-33B-Hazardous Wildlife Attractants On Or Near Airports. Specifically, the AC provides airport operators and those with whom they cooperate guidance to assess and address potentially hazardous wildlife attractants when locating new facilities and implementing certain land-use practices on or near public-use airports. However, with the exception of the siting of new waste disposal operations (FAA AC 150/520034-Construction or Establishment of Landfills Near Public Airports), the FAA's regulatory role over land uses off of airport property is limited. Thus, communication and collaboration between airport operators, other U.S. Federal agencies, municipal governments, and developers is encouraged (see AC 150/5200-33B).

Also, the FAA recognizes that most public-use airports have large tracts of open, undeveloped land that provide added margins of safety and noise mitigation. However, these areas also can pose hazards to aviation if they attract wildlife to an airport's approach or departure airspace or air operations area (AOA). The AOA refers to areas on the airport designated for takeoff, landing, and surface maneuvers of aircraft (CFR Part 139, Subpart D) and within FAA siting criteria for certificated airports (i.e., within $1.5-\mathrm{km}$ of a runway for airports servicing piston-powered aircraft only and within $3.0 \mathrm{~km}$ of a runway for airports servicing turbine-powered aircraft). For all airports, the FAA recommends a distance of 5 statute 
miles ( $8 \mathrm{~km}$ ) between the farthest edge of the airport's AOA and the hazardous wildlife attractant if the attractant could contribute to wildlife movement into or across the approach or departure airspace.

In addition, AC 150/5200-33B states that constructed or natural areas, such as poorly drained locations, detention/retention ponds, roosting habitats on buildings, landscaping, odor-causing rotting organic matter (putrescible waste) disposal operations, wastewater treatment plants, agricultural or aquaculture activities, surface mining, or wetlands can provide wildlife with habitat for foraging, loafing, breeding, and escape from predators. Also, facilities such as restaurants, taxicab staging areas, rental car facilities, aircraft viewing areas, and public parks are included in the AC because they frequently serve as sources of food for wildlife. However, like the ICAO $(1991,2002)$ recommendations, guidance relating wildlife use of airport facilities or undeveloped areas to aspects of facility design and area, proximity to other habitat features, sitespecific operational and management procedures, or land-cover types and seasonality is absent. Instead, both the AC 150/5200-33B and the FAA Airport Wildlife Hazard Mitigation (WHM) homepage (http://wildlife-mitigation.tc.faa.gov/public_html/index.html) provide links to agency, university, and international information for management of hazardous wildlife. However, the FAA does not include in its AC or WHM homepage a selection of references from the peer-reviewed literature pertaining directly or indirectly to the various areas of on-going research pertaining to wildlife strikes.

With regard to the management of airport properties, the airport must be considered a component of the landscape and, therefore, contributing to and subject to local- and landscape-level factors affecting wildlife populations. Inherent to successful management of wildlife hazards to aviation at local and landscape levels is collaboration within municipal, state, and provincial governments, and internationally. The ICAO guidelines establish a foundation for such collaboration, and the EU is moving toward mandatory reporting of wildlife strikes to the ICAO (EU, 2003). In the USA, groundwork for such collaborative efforts is exemplified by the 2003 Memorandum of Agreement between the FAA, U.S. Air Force, the U.S. Army, U.S. Environmental Protection Agency, U.S. Fish and Wildlife Service, and the U.S. Department of Agriculture to address "aircraft-wildlife strikes"; the 2005 Memorandum of Understanding (MOU) between the U.S. Department of Transportation, FAA, and the U.S. Department of Agriculture for mitigating wildlife hazards to aviation (No. 12-34-71-0003-MOU); and the 2006 MOU between the National Association of State Aviation Officials and the U.S. Department of Agriculture (APHIS 06-7100-0202-MU) to seek a mutual goal of alleviating wildlife hazards to aviation. Finally, airport managers also must adhere to national legislation affecting wildlife populations (e.g., the U.S. Endangered Species Act of 1973) and international treaties (e.g., the Migratory Bird Treaty Act of 1918 between the USA, Canada, Japan, Mexico, and Russia; the International Union for Conservation of Nature).

\section{Information gaps}

Quantifying wildlife hazards to aviation safety is critical to airport planning, particularly evaluations of future capacity needs. However, data are generally lacking with regard to the contribution to wildlife hazards posed by specific land uses, particularly within airport approach/departure zones. In the following sections we address research needs for three prominent land-use practices on or near airports relative to wildlife use: (1) stormwater management, (2) land covers, and (3) natural areas. We also discuss how data on land use and wildlife species can be integrated into airport planning. Again, our focus is primarily on aviation in the USA.

\subsection{Stormwater management}

Unlike other land uses on and near airports, the containment of stormwater is necessary for safe operations on runways, taxiways, and aprons, but also as a means to control the entry of contaminants into natural water systems (AC 150/5200-33B, ICAO 2002). However, the containment of stormwater runoff can also create a wildlife attractant. For U.S. airports, the AC 150/5200-33B addresses this issue by suggesting that water runoff be held for a maximum of 48 hrs by use of detention ponds. A detention pond is designed to temporarily hold a maximum amount of water while draining to another location. In contrast, a retention pond is designed to hold a set amount of water indefinitely. Various other methods of covering standing water are offered in the AC as management options. In addition, sub-surface flow (SSF) wetlands for runoff treatment are in use at some airports (Higgins and Liner, 2007), thus removing the attractant. However, SSF designs do not necessarily supplant the need for surface containment. Design considerations for aboveground stormwater-management facilities to reduce use by wildlife are not outlined by the FAA or ICAO; only recently has this issue been addressed relative to aviation safety (Blackwell et al., 2008).

Blackwell et al. (2008) monitored avian use of 30 stormwatermanagement ponds in Washington (USA), over one year and evaluated the fit of six a priori models relative to pond use by 13 avian groups. Their findings indicate that the primary focus in minimizing bird use should be on reducing pond perimeter via circular or linear designs. The authors also recommend that ponds should be located so as to maximize the distance between stormwatermanagement ponds and other water resources, particularly within $1 \mathrm{~km}$ of a planned stormwater facility. Based on this study, new research is underway to quantify avian use of stormwatermanagement facilities found within the approach/departure zones of other U.S. airports (J. Armstrong, Auburn University, School of Forestry and Wildlife Sciences, Auburn, AL, USA, personal communication). Researchers on a companion study are investigating physical modifications to stormwater-management ponds, biotic and synthetic water-treatment methods, and hydrology scenarios to effectively treat runoff while minimizing use by birds (C.E. Boyd, Auburn University, Dept. of Fisheries and Allied Aquacultures; K.H. Yoo, Auburn University, Dept. of Biosystems Engineering, personal communication). In addition, there is a critical need for benefit:cost assessments with regard to retrofitting existing stormwater facilities on an near airports with synthetic liners (to control emergent vegetation), covers, netting, or grid systems to reduce use by birds.

\subsection{Land cover}

The choice of land cover at airports usually depends on airoperations safety regulations, economic considerations, location, and wildlife-hazard management. From an air-operations perspective, land cover should prevent soil erosion and blowing dust and debris, require little maintenance, and provide a firm braking surface near runways for aircraft during emergencies (Blokpoel, 1976) Wildlife managers must work under these constraints when contemplating land-cover types that will not attract hazardous wildlife. Historically, the principal land cover at airports has been turf grass, even though large expanses of turf grass can attract various hazardous bird species (e.g., European starlings [Sturnus vulgaris], Canada geese [Branta canadensis], and various gulls [Larus spp.]), and there is no consensus regarding the species composition and height of grass that best reduces wildlife hazards (Mead and Carter, 1973; Brough and Bridgman, 1980; Seamans et al., 2007; Washburn and Seamans, 2007; Washburn et al., 2007). However, regardless of species composition and height, turf-grass maintenance at airports is expensive (ICAO, 1991, 2002). An attractive alternative to turf grass on some portions of airport properties would be the 
establishment of land-cover types that generate income rather than consume resources (ICAO, 2002). Such land-cover options would be especially beneficial for smaller airports that operate on limited budgets (Dolbeer et al., 2008).

An obvious alternative to turf grass is agriculture, and in an era when plant agriculture includes food crops, landscaping vegetation, and crops for biofuels, potential revenue-producing land covers for airports abound. However, the ICAO and FAA recommend against using airport property for most types of agriculture because of the potential to attract hazardous wildlife (ICAO, 1991; AC 150/5200-33B). Specifically, the AC 150/5200-33B instructs certificated airports to refrain from using airport land for agriculture unless "... the airport has no financial alternative to agricultural crops to produce income necessary to maintain the viability of the airport". Should an airport consider agriculture for revenue, cropdistance guidelines are provided in AC 150/5300-13-Airport Design, Appendix 17, Minimum Distances between Certain Airport Features and Any On-Airport Agricultural Crops. Notably, these minimumdistance rules for agriculture operations are not based on research characterizing wildlife use of specific crops. Further, despite the hazards ostensibly inherent to agriculture at airports, many small airports in the USA which are not regulated by the FAA lease substantial portions of airport properties for agricultural production. In a recent study of 10 small airports in Indiana, USA, row-crop fields (corn and soybeans) covered approximately $20 \%$ of the combined airport properties, and some row-crop fields were within $20 \mathrm{~m}$ of active runways (DeVault et al., 2008).

To begin consideration of the types of agriculture that might be compatible with airport operations from a wildlife-hazard perspective, one must consider recognized wildlife-habitat relationships in agricultural landscapes. Many farmland bird populations have declined in recent decades because of agricultural intensification in Europe (Donald et al., 2001, 2002; Benton et al., 2003) and the USA (Blackwell and Dolbeer, 2001; Murphy, 2003; Peterjohn, 2003; Krapu et al., 2004). Increases in average field size, enhanced weed and invertebrate pest control, and the shift from agricultural mosaics to monocultures of row crops has resulted in the homogenization of agricultural landscapes (Arnold, 1983; Benton et al., 2003). The reduction in available nesting habitats (Best et al., 1995; Blackwell and Dolbeer, 2001), invertebrate populations (Wilson et al., 1999), weed seeds (Wilson et al., 1999; Krapu et al., 2004), and waste grain (Krapu et al., 2004) all have contributed to reduced bird diversity and population sizes in present-day agricultural landscapes (Benton et al., 2003; Tscharntke et al., 2005; however, see reference to the wood pigeon Columba palumbus in Raven et al., 2007).

Even in relatively diverse agricultural landscapes, birds use rowcrop fields infrequently compared to adjacent habitat types. Birds are generally more abundant in wooded fence rows, grassed waterways, and woodlots, where nesting locations and food resources are more abundant (Blokpoel, 1976; Best et al., 1995, 2001; Patterson and Best, 1996; McMaster and Davis, 2001). Frequent anthropogenic disturbance, low plant species diversity, and the use of pesticides contribute to the relative lack of birds found in rowcrop fields (Best et al., 1995). In a review of habitat use by farmland birds in the midwestern USA, only red-winged blackbirds (Agelaius phoeniceus) were considered "very abundant" in any agricultural habitat (grass hayfields), and no species were considered "very abundant" or "abundant" in pastures or row crops (Best et al., 1995). Furthermore, relatively few species nest in row-crop fields compared to grassland habitats (Patterson and Best, 1996). Most species use row-crop fields only for foraging, preferring to nest in adjacent habitats (Best et al., 1990, 1995; Murphy, 2003).

Furthermore, agricultural fields also serve as avian foraging habitat during winter (Wilson et al., 1996; Perkins et al., 2000). Fields that are completely plowed under after harvest ("conven- tional tillage") usually undergo a high incidence of bird use for a short period of time, because of attraction to seeds and invertebrates brought to the surface (Wilson et al., 1996). Fields that are partially tilled or not tilled at all ("conservation tillage"), thereby leaving some crop residue on the soil surface (Best, 1986), generally attract more birds throughout the winter period than conventional tillage (Flickinger and Pendleton, 1994; Butler et al., 2005; but see Perkins et al., 2000). However, as is the case during the growing season, grass fields generally are preferred by invertebrate-feeding birds over crop fields during winter due to decreased invertebrate abundances in crop fields (Tucker, 1992).

Although birds are generally less abundant in crop fields than in adjacent habitat types, over 50 bird species have been documented using row-crop fields during the breeding season in the midwestern USA (Best et al., 1995). Further, extensive work has been directed at bird damage to agriculture (e.g., blackbird [Icteridae] damage to corn (Dolbeer et al., 1984), sunflowers (Blackwell et al., 2003; Peer et al., 2003), and vegetables (Mott et al., 1972); waterfowl damage to cereal grains (Mott et al., 1972), and European starling damage to fruits (Feare, 1985; Stevens, 2008)). In a review of studies documenting bird damage to crops in the USA, Sterner et al. (1984) found damage reported for grains, seeds, and silages ( 18 of 24 crop types), vegetables (15 of 25 ), fruits (17 of 20 ), and nuts (5 of 6). However, Sterner et al. (1984) found no studies documenting bird damage to cotton, cottonseed, dry edible beans, hops, sweet potatoes, soybeans, and several types of fruits and vegetables. Sixty-nine species of birds were reported to damage crops, although blackbirds were the most frequently cited species linked to crop damage. Blackbirds are likely the most economically important bird-species group affecting agriculture in the USA (Sterner et al., 1984; Conover, 2002; Blackwell et al., 2003). Interestingly, despite the abundance of soybean fields in the USA, soybeans are not a preferred food for birds (Krapu et al., 2004), and birds rarely cause damage in soybean fields (Sterner et al., 1984; Humberg et al., 2007). It is worth noting, however, that birds often forage for invertebrates in fields where no wildlife damage occurs (Best et al., 1990; Krapu et al., 2004; Humberg et al., 2007).

Because all crops do not attract birds equally, the opportunity exists to identify revenue-producing crops and practices (e.g., irrigation requirements) that are compatible with minimizing wildlife hazards at airports. However, airport environments differ from rural landscapes, offering grassland, pavement, and structural habitats. Thus, studies are needed to understand how hazardous bird species use crop fields and various tillage regimens in airport environments. Movement patterns and home ranges of hazardous birds in airport environments will likely be important in determining potential use of airport crop fields. Further, nesting locations of these species in airport habitats should be identified so they can be eliminated or altered to be unattractive. In addition, little is known concerning wildlife use of non-traditional field crops (e.g., meadowfoam [ Limnanthes alba]; Alternative Field Crops Manual, 1989), some of which might prove suitable for use on airports. It is also important to note that agriculture at airports has implications for mammalian (e.g., white-tailed deer [Odocoileus virginianus]) as well as bird hazards, especially at small airports where funding is often limited and fending inadequate (DeVault et al., 2008; Dolbeer et al., 2008).

\subsection{Natural areas}

Various types of human disturbance have been shown to have negative effects on wildlife (e.g., Canaday, 1996; Reed and Merenlender, 2008), particularly in highly urbanized landscapes (Fernández-Juricic, 2000a). However, airports have relatively low levels of at least one type of human disturbance (e.g., recreational activities) due to heightened security. Minimal pedestrian disturbance can enhance the suitability of different habitat types (forests, 
grasslands, water sources) in terms of foraging and breeding opportunities (Fernández-Juricic, 2002). Furthermore, the diversity of habitats at airports (Baker and Brooks, 1981) might exceed that found in other landscape elements, like urban parks or residential areas. For example, raptors exploit the availability of open foraging areas (often with higher densities of small mammals), perch availability, and nesting habitats on airports (Baker and Brooks, 1981; Linnell et al., 1996; Kelly, 1999; Avery and Genchi, 2004; Blackwell and Wright, 2006). Airports also provide some of the only remaining extensive areas of grassland habitat in heavily urbanized regions like the northeast USA, and some contend that these habitats should be managed for nesting avifauna (Osborne and Peterson, 1984; Vickery et al., 1994; Houston and Bowen, 2001; see also Kershner and Bollinger, 1996).

However, simply setting aside undeveloped areas as natural areas on airports can pose negative effects for aviation safety and wildlife species. For example, there is a general presupposition of a direct relationship between the local density of a given species of bird (whether hazardous to aviation or not) and the rate of bird strikes (Sodhi, 2002). Empirical evidence supports this association in some species (e.g., Linnell et al., 1996; Belant, 1997; Byron and Downs, 2002; Baxter and Allan, 2008). Further, airports can function as ecological traps (Kokko and Sutherland, 2001) for some endangered or threatened species due to direct collisions with aircraft (e.g., lappet-faced vulture [Torgos tracheliotus], black-footed albatross [Phoebastria nigripes], Townsend's shearwater [Puffinus auricularis]; Dolbeer and Wright, 2008) or indirect effects of wildlife-control programs targeting other species. Also, some locally protected species may be affected negatively by air traffic through indirect effects. For instance, military aircraft have been shown to disturb grey heron (Ardea cinerea) adults incubating and feeding young, and ultimately facilitating the access to nest predators (Kitowski, 2001). Thus, to safely and effectively incorporate biodiversity and conservation efforts into airport-planning models, information is needed on the direct effects of airport operations and potential indirect effects on species populations that use airport habitats.

Unfortunately, we know little about how species abundance/richness varies between airports and other landscape elements. For example, species richness can differ considerably across various urban landscape elements (Fernández-Juricic, 2000b; Sandstrom et al., 2006). If an airport acts as a population sink, it is likely that individuals from source areas (either of the same or related species) might reoccupy the vacated niches (Brown et al., 2001b), which may require reducing the accessibility of those individuals to the airport to control the population. On the other hand, if airports act as sources (Brown et al., 2001a), control of breeding populations on the airport could be opposed, especially for species of concern (e.g., bald eagle [Haliaeetus leucocephalus] nesting at Orlando International Airport, Florida, USA; see Metcalf, 2007). Also, severe local control of population growth (on or near an airport) could reduce the dispersal of individuals into other populations and potentially affect the regional persistence of a species. This latter scenario could require carefully planned reintroduction efforts.

Successful planning and management for select, non-hazardous wildlife species on airport properties must, therefore, consider inter-specific variations in some processes that can affect local populations, such as density-dependence, behavioral responses to aircraft or aversive methods (speed of reaction, sensitization, habituation, etc.), and movement between suitable patches within and surrounding an airfield. We suggest that planners consider implementing the concept of buffer areas, which has been used in conservation biology and wildlife management (Wells and Brandon, 1993; Shafer, 1999a). This concept has been applied both at the landscape scale (hereafter, landscape buffer areas) and at the patch scale (hereafter, patch buffer areas). A landscape buffer area (also known as a buffer zone) is an area surrounding critical habitat for a population or a community that also can serve as an environmental "cushion" to minimize external disturbances (Sayer, 1991; Shafer, 1999b). Similarly, a patch buffer area (also known as a set-back zone) denotes a minimum area of critical habitat for an individual or a group of individuals concentrated in space (breeding colony, roost; Vos et al., 1985; Fox and Madsen, 1997; FernándezJuricic et al., 2005).

The delineation of a landscape buffer area is based on a threshold distance from a source of disturbance at which the density of a species or species richness increases substantially (Reijnen et al., 1995; Miller et al., 1998; Sinclair et al., 2005). Usually, this threshold distance establishes a minimum width of habitat required for protection (Palomino and Carrascal, 2007).

Conceptually, the establishment of patch buffer areas is related to the theory of anti-predator behavior (Lima, 1998), because it assumes that individuals perceive humans (or human-related activities) as threats and respond to them by becoming alert and eventually fleeing (Frid and Dill, 2002). Subsequently, estimation of patch buffer areas is based on the distance at which animals become fearful of humans (Knight and Skagen, 1988; Knight and Temple, 1995; Richardson and Miller, 1997). First, minimum approaching distances (minimum horizontal distance of non-intrusion by humans that would preclude disturbance; Rodgers and Smith, 1995; Rodgers and Schwikert, 2002) are calculated. Second, patch buffer areas are estimated using the minimum approaching distance as the radius of a circular area (Fox and Madsen, 1997). In a conservation context, patch buffer areas have helped limit the amount of disturbance to wildlife through a reduction in detection and avoidance behavior by birds (Rodgers and Schwikert, 2002). This concept can be reversed for bird-aircraft scenarios so that management techniques can be applied within patch buffer areas to enhance the probability of aircraft detection and avoidance. However, the assertion that wildlife respond to human activities (e.g., aircraft) in similar ways to those of predators is a key assumption that requires empirical testing across a wide range of species to establish models for bird-strike research (e.g., Blumstein et al., 2003, 2005; Blackwell and Bernhardt, 2004; Blackwell et al., 2009).

In summary, landscape buffer areas offer opportunities for sustainable development on and near airports without necessarily enhancing wildlife hazards. Patch buffer areas would allow us to better define the proportional area of airports in which birds (as well as other wildlife) and aircraft overlap, and consequently the spatial range of certain wildlife management control techniques. Overall, the adoption of the buffer-area approach into airport planning offers a means of targeting select, nonhazardous species and their habitats for conservation in planning models, and with regard to aviation safety.

\section{Land use and wildlife-strike risk}

As the footprint of an airport on local habitats changes (via operations, land management, expansion, etc.), the wildlife communities using those habitats are necessarily affected in richness and abundance (e.g., Fernández-Juricic, 2004; Chace and Walsh, 2006). Further, though airport development often degrades ecosystems, some species respond positively to human-induced changes to the landscape. Thus, airport planners must weight designs affecting functionality of the airport (e.g., stormwater systems), novel revenue-producing land uses, and considerations for biodiversity and species conservation relative to potential wildlife-strike hazards.

Schafer et al. (2007) noted that effective prioritization of species management on airports entails an assessment of the realistic 
potential for damage associated with wildlife strikes, and suggested the implementation of risk assessment that reflects an index of species frequency within critical locations on and near the airport and associated strike-damage metrics. A risk assessment has two basic phases (Graham et al., 1991): (1) a conceptual understanding of the sources of the problem (e.g., factors contributing to wildlife hazards to aviation), realistic endpoints or potential events (e.g., a hull loss; see Dolbeer et al., 2000; Dolbeer and Wright, 2009), and mechanisms by which the sources contribute to the defined endpoints; and (2) a spatiotemporal estimate of exposure to the problem sources and a quantification of potential effects. In the context of an airport, seasonal demographic cycles of species using particular habitats could be evaluated relative to species abundance estimates within critical airspace (e.g., agriculture near an airport; Baxter and Robinson, 2007; runway protection zones; Schafer et al., 2007) to better discern the contribution of land use to wildlife-strike risk. Thus, the wildlife-strike risk assessment should include land-use data and, at minimum, species relative abundance estimates and strike statistics. Other components include data on aircraft types serviced by the airport and number of movements relative to seasonal abundance estimates of hazardous species. Conceptually, these data components would be maintained within a single database, such as the FAA National Wildlife Strike Database (NWSD).

In 1995, the FAA, through an interagency agreement with the U.S. Department of Agriculture, Wildlife Services (WS), initiated a project to obtain more objective estimates of the magnitude and nature of the national wildlife strike problem for civil aviation. This effort involves the (1) editing of all strike reports (FAA Form 52007, Birds/Other Wildlife Strike Report) received by the FAA since 1990; (2) entering strike data into the NWSD; (3) supplementing FAAreported strikes with additional, non-duplicated strike reports from other sources; and (4) assisting the FAA with the production of reports summarizing the results of analyses of these data. The analyses conducted by WS on strike data focus on the economic costs of wildlife strikes, the magnitude of safety issues, wildlife species involved, types of damage, height and phase of flight during which strikes occur, and seasonal patterns (Dolbeer and Wright, 2008; see also Dolbeer et al., 2000; DeVault et al., 2005; Blackwell and Wright, 2006; Dolbeer, 2006b).

However, the NWSD contains no current land-use data for the airport or within the FAA separation distances. For example, the location of strikes occurring within the approach/departure zones (e.g., the 8-km separation for airports receiving turbine-powered aircraft) is assigned as that of the airport. Without data on the landscape matrix surrounding an airport and wildlife use of these habitats, the necessary covariates for assessing wildlife-strike risk associated with current or planned land uses are limited. In the absence of site-specific data, we suggest use of frequency distributions reflecting species seasonal occurrence in similar habitats or long-term data sets reflecting species trends (e.g., Breeding Bird Survey; Sauer et al., 2008), as well as consideration of wildlifestrike statistics for geographically similar locations. We note, also, that climate-induced changes in migration and nesting phenology of some bird populations could affect local population dynamics (e.g., Crick, 2004; Johnson et al., 2005; Both et al., 2006) and, subsequently, species-specific strike risk. Estimates of species-specific damage resulting from wildlife strikes are available from the NWSD (see Dolbeer and Wright, 2008) and could be used as surrogate data for similar species.

\section{Conclusions}

Collaborative efforts to more accurately assess goals for airport capacity needs, revenue, and sustainability in light of risks posed to aviation safety by wildlife populations are needed. International legislation guiding airport land-use planning recognizes wildlife hazards to aviation, but the recommendations are often general and in some cases conflicting. Further, with a world-wide focus on wildlife strikes and on-going international research, we encourage a proactive communication between the ICAO and aviation organizations within its member states (e.g., the FAA), such that science-based management protocols form the foundation for guidelines to reduce wildlife hazards to aviation. Moreover, we suggest that an airport is a component of the landscape and, therefore, contributes to and is subject to local- and landscape-level factors that affect wildlife populations. In turn, those same wildlife populations pose a level of risk to aviation safety. We, therefore, encourage continued and new research in four types of land use that affect airport operations in the USA and internationally: (1) management of stormwater on and near airports so as to meet local and national requirements for water treatment, while reducing use by species documented as hazardous to aviation; (2) wildlife (particularly bird) use of agricultural crops and various tillage regimens, as well as the periodicity and seasonality of use relative to other landscape uses, such as turf grass; (3) quantification of species richness and abundance relative to elements within and between landscapes, so as to better understand the role of the airport as a component of the landscape in explaining species population dynamics; and (4) use of buffer areas in planning for sustainable development on and around airports. Finally, we encourage the development and maintenance of datasets that will allow realistic assessment of wildlife-strike risk relative to current airport conditions as well as to anticipated increases in capacity.

\section{Acknowledgements}

The U.S. Department of Agriculture, Animal and Plant Health Inspection Service, Wildlife Services, National Wildlife Research Center supported this research. The authors received salary and logistical support from their respective institutions. In addition, we thank A. de Hoon and E. Poggiali for logistical assistance. We greatly appreciate reviews of earlier drafts of this manuscript by T.W. Seamans and L.A. Yako.

\section{References}

Aaronson, R.J., 2007. Leadership and action: a winning combination. ICAO J. 5, 36. Abeyratne, R.I.R., 2000. Management of airport congestion through slot allocation. J. Air Transport Manage. 6, 29-41.

Airport Technology, 2009, 23 February. Expansion bucks the economic trend. Web site: http://www.airport-technology.com/features/feature49850/.

Allan, J.R., 2002. The costs of bird strikes and bird strike prevention. In: Clark, L., Hone, J., Shivik, J.A., Watkins, R.A., Vercauteren, K.C., Yoder, J.K. (Eds.), Human Conflicts with Wildlife: Economic Considerations, Proceedings of the Third NWRC Special Symposium. National Wildlife Research Center, Fort Collins, CO, USA, pp. 147-153.

Alternative Field Crops Manual, 1989. University of Minnesota CAPAP, MN, USA

Arnold, G.W., 1983. The influence of ditch and hedgerow structure, length of hedgerows, and area of woodland and garden on bird numbers on farmland. J. Appl. Ecol. 20, 731-750.

Avery, M.L., Genchi, A.C., 2004. Avian perching deterrents on ultrasonic sensors at airport wind-shear alert systems. Wildl. Soc. Bull. 32, 718-725.

Baker, J.A., Brooks, R.J., 1981. Distribution patterns of raptors in relation to density of meadow voles. Condor 83, 42-47.

Baxter, A.T., Allan, J.R., 2008. Use of lethal control to reduce habituation to blank rounds by scavenging birds. J. Wildl. Manage. 72, 1653-1657.

Baxter, A.T., Robinson, A.P., 2007. Monitoring and influencing feral Canada goose (Branta canadensis) behaviour to reduce birdstrike risks to aircraft. Int. J. Pest Manage. 53, 341-346.

Belant, J.L., 1997. Gulls in urban environments: landscape-level management to reduce conflict. Landscape Urban Plan. 38, 245-258.

Benton, T.G., Vickery, J.A., Wilson, J.D., 2003. Farmland biodiversity: is habitat heterogeneity the key? Trends Ecol. Evol. 18, 182-188.

Best, L.B., 1986. Conservation tillage: ecological traps for nesting birds? Wildl. Soc. Bull. 14, 308-317.

Best, L.B., Bergin, T.M., Freemark, K.E., 2001. Influence of landscape composition on bird use of rowcrop fields. J. Wildl. Manage. 65, 442-449. 
Best, L.B., Freemark, K.E., Dinsmore, J.J., Camp, M., 1995. A review and synthesis of habitat use by breeding birds in agricultural landscapes of Iowa. Am. Midl. Nat. 134, 1-29.

Best, L.B., Whitmore, R.C., Booth, G.M., 1990. Use of cornfields by birds during the breeding season: the importance of edge habitat. Am. Midl. Nat. 123, 84-99.

Blackwell, B.F., Avery, M.J., Watts, B.D., Lowney, M.S., 2007. Demographics of black vultures in North Carolina. J. Wildl. Manage. 71, 1976-1979.

Blackwell, B.F., Bernhardt, G.E., 2004. Efficacy of aircraft landing lights in stimulating avoidance behavior in birds. J. Wildl. Manage. 68, 725-732.

Blackwell, B.F., Dolbeer, R.A., 2001. Decline of the red-winged blackbird population in Ohio correlated to changes in agriculture (1965-1996). J. Wildl. Manage. 65, 661-667.

Blackwell, B.F., Fernández-Juricic, E., Seamans, T.W., Dolans, T., 2009. Avian visual configuration and behavioural response to object approach. Anim. Behav. 77, 673-684.

Blackwell, B.F., Huszar, E., Linz, G., Dolbeer, R.A., 2003. Lethal control of red-winged blackbirds to manage damage to sunflower: an economic evaluation. J. Wildl. Manage. 67, 818-828.

Blackwell, B.F., Schafer, L.M., Helon, D.A., Linnell, M.A., 2008. Bird use of stormwatermanagement ponds: decreasing avian attractants on airports. Landscape Urban Plan. 86, 162-170.

Blackwell, B.F., Wright, S.E., 2006. Collisions of red-tailed hawks (Buteo jamaicensis), Turkey (Cathartes aura), and black vultures (Coragyps atratus) with aircraft: implications for bird strike reduction. J. Raptor Res. 40, 76-80.

Blokpoel, H., 1976. Bird Hazards to Aircraft. Clarke, Irwin \& Company Limited.

Blumstein, D.T., Anthony, L.L., Harcourt, R., Ross, G., 2003. Testing a key assumption of wildlife buffer zones: is flight initiation distance a species-specific trait? Biol. Cons. 110, 97-100.

Blumstein, D.T., Fernandez-Juricic, E., Zollner, P.A., Garity, S.C., 2005. Inter-specific variation in avian responses to human disturbance. J. Appl. Ecol. 42, 943-953.

Both, C., Bouwhuis, S., Lessells, C.M., Visser, M.E., 2006. Climate change and population declines in a long-distant migratory bird. Nature 441, 81-83.

Brough, T.E., Bridgman, C.J., 1980. An evaluation of long-grass as a bird deterrent on British airfields. J. Appl. Ecol. 17, 243-253.

Brown, K.M., Erwin, R.M., Richmond, M.E., Buckley, P.A., Tanacredi, J.T., Avrin, D., 2001b. Managing birds and controlling aircraft in the Kenney Airport-Jamaica Bay wildlife refuge complex: the need for hard data and soft opinions. Environ. Manage. 28, 207-224.

Brown, K.M., Tims, J.L., Erwin, R.M., Richmond, M., 2001a. Changes in the nesting populations of colonial waterbirds in Jamaica Bay Wildlife Refuge, New York, 1974-1998. Northeastern Nat. 8, 275-292.

Butler, S.J., Bradbury, R.B., Whittingham, M.J., 2005. Stubble height affects the use of stubble fields by farmland birds. J. Appl. Ecol. 42, 469-476.

Butterworth, M., 2008, 19 November. UK economy will suffer due to insufficient air links, BA chief warns. Telegraph, London, UK. Web site: http://telegraph.co.uk/finance/financetopics/recession/3484184/UK.

Byron, J., Downs, C.T., 2002. Bird presence at Oribi Airport and recommendations to avoid bird strikes. S. African J. Wildl. Res. 32, 49-58.

Canaday, C., 1996. Loss of insectivorous birds along a gradient of human impact in Amazonia. Biol. Conserv. 77, 63-77.

Chace, J.F., Walsh, J.J., 2006. Urban effects on native avifauna: a review. Landscape Urban Plan. 74, 46-69.

Cleary, E.C., Dolbeer, R.A., 2005. Wildlife Hazard Management at Airports, second ed. Federal Aviation Administration, Office of Airport Safety and Standards, Airport Safety and Compliance Branch, Washington, DC, USA.

Conover, M.R., 2002. Resolving Human-Wildlife Conflicts. Lewis, Boca Raton, FL, USA.

Crick, H.Q., 2004. The impact of climate change on birds. Ibis 146, 48-56.

DeVault, T.L., Kubel, J.E., Glista, D.J., Rhodes Jr., O.E., 2008. Mammalian hazards at small airports in Indiana: impact of perimeter fencing. Human-Wildl. Confl. 2, 240-247.

DeVault, T.L., Reinhart, B.D., Brisbin Jr., I.L., Rhodes Jr., O.E., 2005. Flight behavior of black and turkey vultures: implications for reducing bird-aircraft collisions. J. Wildl. Manage. 69, 592-599.

Dolbeer, R.A., 2006a. Birds and aircraft are competing for space in crowded skies. ICAO J. 3, 21-24.

Dolbeer, R.A., 2006b. Height distribution of birds as recorded by collisions with civil aircraft. J. Wildl. Manage. 70, 1345-1350.

Dolbeer, R.A., 2007. Managing the risks of bird strikes. Int. Airport Rev. 2, 61-64

Dolbeer, R.A., Begier, M.J., Wright, S.E., 2008. Animal ambush: the challenge of managing wildlife hazards at general aviation airports. Corp. Aviat. Saf. Sem. 53, $1-12$.

Dolbeer, R.A., Eschenfelder, P., 2002. Population increases of large birds, airworthiness standards and high-speed flight: a precarious combination. In: Proceedings of the 55th International Air Safety Seminar, Dublin, Ireland. Flight Safety Foundation, Alexandria, VA, USA, pp. 273-281.

Dolbeer, R.A., Woronecki, P.P., Stehn, R.A., 1984. Blackbird (Agelaius phoeniceus) damage to maize: crop phenology and hybrid resistance. Prot. Ecol. 7, 43-63.

Dolbeer, R.A., Wright, S.E., 2008. Wildlife strikes to civil aircraft in the United States, 1990-2007. U.S. Department of Transportation, Federal Aviation Administration, Office of Airport Safety and Standards, Serial Report No. 14, Washington, DC, USA, $57 \mathrm{pp}$.

Dolbeer, R.A., Wright, S.E., 2009. Safety management systems: how useful will the FAA National Wildlife Strike Database be? Human-Wildl. Confl. 3, 167178.

Dolbeer, R.A., Wright, S.E., Cleary, E.C., 2000. Ranking the hazard level of wildlife species to aviation. Wildl. Soc. Bull. 28, 372-378.
Donald, P.F., Green, R.E., Heath, M.F., 2001. Agricultural intensification and the collapse of Europe's farmland bird populations. Proc. Royal Soc. Lond. B 68, 25-29.

Donald, P.F., Pisano, G., Rayment, M.D., Pain, D.J., 2002. The common Agricultura Policy, EU enlargement and the conservation of Europe's farmland birds. Agric. Ecosystems Environ. 89, 167-182.

European Union, 2001. Directive 2001/42/EC of the European Parliament and of the Council on the Assessment of the Effects of Certain Plans and Programmes on the Environment, Luxembourg.

European Union, 2003. Directive 2003/42/EC of the European Parliament and of the Council of 13 June 2003 on occurrence reporting in civil aviation, Luxembourg.

Feare, C.J., 1985. The Starling. Shire Publications, Princes Risborough, United Kingdom.

Federal Aviation Administration, 2006. Report to Congress. National Plan of Integrated Airport Systems (NPIAS) 2007-2011.

Federal Aviation Administration, 2008a. Procedures for handling airspace matters. Section 2. Class B Airspace Standards. Order JO 7400.2G.

Federal Aviation Administration, 2008b. FAA aerospace forecast fiscal years (2008-2025). Web site: http://www.faa.gov/data_statistics/aviation/aerospace forecasts/2008-2025/.

Fernández-Juricic, E., 2000a. Local and regional effects of pedestrians on forest birds in a fragmented landscape. Condor 102, 247-255.

Fernández-Juricic, E., 2000b. Avifaunal use of linear strips in an urban landscape. Conserv. Biol. 14, 513-521.

Fernández-Juricic, E., 2002. Can human disturbance promote nestedness? A case study with birds in an urban fragmented landscape. Oecologia 131, 269-278.

Fernández-Juricic, E., 2004. Spatial and temporal analysis of the distribution of forest specialists in an urban-fragmented landscape (Madrid, Spain): implications for local and regional bird conservation. Landscape Urban Plan. 69, 17-32.

Fernández-Juricic, E., Venier, P., Renison, D., Blumstein, D.T., 2005. Sensitivity of wildlife to spatial patterns of recreationist behavior: a critical assessment of minimum approaching distances and buffer areas for grassland birds. Biol. Conserv. $125,225-235$.

Flight Safety Foundation, 2000. Flight Safety Foundation approach-and-landing accident reduction briefing note 4.2-energy management. Flight Saf. Digest. August-November, 75-80.

Flickinger, E.L., Pendleton, G.W., 1994. Bird use of agricultural fields under reduced and conventional tillage in the Texas Panhandle. Wild. Soc. Bull. 22, 34-42.

Fox, A.D., Madsen, J., 1997. Behavioural and distributional effects of hunting disturbance on waterbirds in Europe: implications for refuge design. J. Appl. Ecol. 34 $1-13$.

Frid, A., Dill, L.M., 2002. Human-caused disturbance stimuli as a form of predation risk. Cons. Ecol. 6 (11), Web site: http://www.consecol.org/vol6/iss1/art11.

Graham, B., Guyer, C., 1999. Environmental sustainability, airport capacity and European air transport liberalization: irreconcilable goals? J. Air Transp. Geog. 7 165-180.

Graham, R.L., Hunsaker, C.T., O’Neil, R.V., Jackson, B.L., 1991. Ecological risk assessment at the regional scale. Ecol. Appl. 1, 196-206.

Higgins, J., Liner, M., 2007. Engineering runoff solutions. Airport Business 21 (3) 22-25.

Houston, C.S., Bowen Jr., D.E., 2001. Upland sandpiper (Bartramia longicauda). In: Poole, A. (Ed.), The Birds of North America, No. 580. Cornell Lab of Ornithology, Ithaca, NY.

Humberg, L.A., DeVault, T.L., MacGowan, B.J., Beasley, J.C., Rhodes Jr., O.E., 2007. Crop depredation by wildlife in northcentral Indiana. Proc. Natl. Wild Turkey Symp. 9, 199-205.

Humphreys, I., Francis, G., Fry, J., 2001. Lessons from airport privatization, commercialization, and regulation in the United Kingdom. Transp. Res. Rec. 1744 9-16.

International Civil Aviation Organization, 1991. Bird control and reduction. Airport Services Manual, Doc 9137-AN/898, Part 3.

International Civil Aviation Organization, 2002. Land use and environmental control. Airport Planning Manual, Doc 9184 AN/902, Part 2.

Johnson, W.C., Millett, B.V., Gilmanov, T., Voldseth, R.A., Guntenspergen, G.R., Naugle D.E., 2005. Vulnerability of northern prairie wetlands to climate change. BioSci. $55,863-872$

Kelly, T.A., 1999. Seasonal variation in birdstrike rate for two North American raptors: Turkey Vulture (Cathartes aura) and red-tailed Hawk(Buteo jamaicensis).J. Raptor Res. 33, 59-62.

Kelly, T.C., Allan, J., 2006. Ecological effects of aviation. In: Davenport, J., Davenport J.L. (Eds.), The Ecology of Transportation: Managing Mobility for the Environment. Springer, The Netherlands, pp. 5-24

Kelly, T.C., O'Callaghan, M.J.A., Bolger, R., 2001. The avoidance behaviour shown by the rook (corvus frugeilegus) to commercial aircraft. In: Pelz, H.-J., Cowan, D.P., Feare, C.J. (Eds.), Advances in Vertebrate Pest Management, pp. 291-299.

Kershner, E.L., Bollinger, E.K., 1996. Reproductive success of grassland birds at eastcentral Illinois Airports. Am. Midl. Nat. 136, 358-366.

Khalafalla, A., El-Rayes, K., 2006. Optimizing airport construction site layouts to minimize wildlife hazards. J. Manage. Engrg. 22, 176-185.

Kitowski, I., 2001. Military impact on a colony of Grey Heron Ardea cinerea protected in the nature reserve. Ekológia (Bratislava) 20, 191-197.

Knight, R.L., Skagen, S.K., 1988. Effects of recreational disturbance on birds of prey: a review. In: R.L. Glinski, et al. (Eds.), Proceedings of the Southwest Raptor Management Symposium and Workshop, Inst. Wild. Res., Natl. Wildl. Fed. Sci. Tech. Ser. No. 11, pp. 355-359.

Knight, R.L., Temple, S.A., 1995. Wildlife and recreationists: coexistence through management. In: Knight, R.L., Gutzwiller, K.J. (Eds.), Wildlife and 
Recreationists: Coexistence Through Management and Research. Island Press, Washington, pp. 327-333.

Kokko, H., Sutherland, W.J., 2001. Ecological traps in changing environments: ecological and evolutionary consequences of a behaviourally mediated Allee effect. Evol. Ecol. Res. 3, 537-551.

Krapu, G.L., Brandt, D.A., Cox Jr., R.R., 2004. Less waste corn, more land in soybeans, and the switch to genetically modified crops: trends with important implications for wildlife management. Wildl. Soc. Bull. 32, 127-136.

Lee, H., Yang, H.M., 2003. Strategies for a global logistics and economic hub: Incheon International Airport. J. Air Transp. Manage. 9, 113-121.

Lima, S.L., 1998. Non-lethal effects in the ecology of predator-prey interactions. BioSci. 48, 25-134.

Linnell, M.A., Conover, M.R., Ohashi, T.J., 1996. Analysis of bird strikes at a tropical airport. J. Wildl. Manage. 60, 935-945.

Mead, H., Carter, A.W., 1973. The management of long grass as a bird repellent on airfields. J. Br. Grassland Soc. 28, 219-221.

Metcalf, J.C., 2007. Bald eagle nest removal: making a case and building consensus among various agencies and organizations for amicable removal. In: Bird Strike Committee Proceedings, Bird Strike Committee USA/Canada, 9th Annual Meeting, Kingston, Ontario.

McMaster, D.G., Davis, S.K., 2001. An evaluation of Canada's permanent cover program: habitat for grassland birds? J. Field Ornithol. 72, 195-325.

Miller, S.G., Knight, R.L., Miller, C.K., 1998. Influence of recreational trails on breeding bird communities. Ecol. Appl. 8, 162-169.

Mott, D.F., West, R.R., DeGrazio, J.W., Guarino, J.L., 1972. Foods of the red-winged blackbird in Brown County, South Dakota. J. Wildl. Manage. 36, 983-987.

Murphy, M.T., 2003. Avian population trends within the evolving agricultural landscape of eastern and central United States. Auk 120, 20-34.

Osborne, D.R., Peterson, A.T., 1984. Decline of the upland sandpiper (Bartramia longicauda) in Ohio: an endangered species. Ohio J. Sci. 84, 8-10.

Palomino, D., Carrascal, L.M., 2007. Threshold distances to nearby cities and roads influence the bird community of a mosaic landscape. Biol. Conserv. 140, 100-109.

Patterson, M.P., Best, L.B., 1996. Bird abundance and nesting success in Iowa CRP fields: the importance of vegetation structure and composition. Am. Midl. Nat. 135, 153-167.

Peer, B.D., Homan, H.J., Linz, G.M., Bleier, W., 2003. Impact of blackbird damage to sunflower: bioenergetic and economic models. Ecol. Appl. 13, 248-256.

Perkins, A.J., Whittingham, M.J., Bradbury, R.B., Wilson, J.D., Morris, A.J., Barnett, P.R., 2000. Habitat characteristics affecting use of lowland agricultural grassland by birds in winter. Biol. Conserv. 95, 279-294.

Peterjohn, B.G., 2003. Agricultural landscapes: can they support healthy bird populations as well as farm products? Auk 120, 14-19.

Rao, A., Pinos, A., 1998. Bird strike threat is best countered by effective wildlife control augmented by land-use management. ICAO J. 53 (8), 5-6, 25.

Raven, M.J., Noble, D.G., Baillie, S.R., 2007. The Breeding Bird Survey 2006. BTO Research Report 471. British Trust for Ornithology, Thetford, United Kingdom.

Reed, S.E., Merenlender, A.M., 2008. Quiet, nonconsumptive recreation reduces protected area effectiveness. Conserv. Lett. 1, 146-154.

Reijnen, R., Foppen, R., Ter Braak, C., Thissen, J., 1995. The effects of car traffic on breeding bird populations in woodland. III. Reduction of density in relation to the proximity of main roads. J. Appl. Ecol. 32, 187-202.

Reiss, B., 2007. Maximizing non-aviation revenue for airports: developing airport cities to optimize real estate and capitalize on land development opportunities. Airport Manage. 1, 284-294.

Richardson, C.T., Miller, C.K., 1997. Recommendations for protecting raptors from human disturbance: a review. Wildl. Soc. Bull. 25, 634-638.

Richardson, W.J., West, T., 2000. Serious birdstrike accidents to military aircraft: updated list and summary. In: Proceedings of the 25th International Bird Strike Committee Meeting, Amsterdam, Netherlands, pp. 67-98.

Rodgers Jr., J.A., Smith, H.T., 1995. Set-back distances to protect nesting bird colonies from human disturbance in Florida. Conserv. Biol. 9, 89-99.

Rodgers Jr., J.A., Schwikert, S.T., 2002. Buffer zone distances to protect foraging and loafing waterbirds from disturbance by personal watercraft and outboardpowered boats. Conserv. Biol. 16, 216-224.

Rusch, D.H., Malecki, R.E., Trost, R.E., 1995. Canada geese in North America. In: LaRoe, E.T., Farris, G.S., Puckett, C.E., Doran, P.D., Mac, M.J. (Eds.), Our Living Resources: A Report to the Nation on the Distribution, Abundance, and Health of U.S. Plants, Animals, and Ecosystems. U.S. Department of the Interior, National Biological Service, Washington, DC, pp. 26-28.
Sandstrom, U.G., Angelstam, P., Mikusinski, G., 2006. Ecological diversity of birds in relation to the structure of urban green space. Landscape Urban Plan. 77, 39-53.

Sauer, J.R., Hines, J.E., Fallon, J., 2008. The North American Breeding Bird Survey, Results and Analysis 1966-2007, Version 5.15.2008, USGS Patuxent Wildlife Research Center, Laurel, MD.

Sayer, J., 1991. Rainforest Buffer Zones: Guidelines for Protected Area Managers, IUCN, Morges, Switzerland.

Schafer, L.M., Blackwell, B.F., Linnell, M.A., 2007. Quantifying risk associated with potential bird-aircraft collisions. In: Irwin, C.L., Nelson, D., McDermott, K.P.(Eds.), Proceedings of the International Conference on Ecology and Transportation. Center for Transportation and the Environment, North Carolina State University, Raleigh, NC, pp. 56-63.

Seamans, T.W., Barras, S.C., Bernhardt, G.E., Blackwell, B.F., Cepek, J.D., 2007. Comparison of two vegetation-height management practices for wildlife control at airports. Human-Wildl. Confl. 1, 97-105.

Shafer, C.L., 1999a. U.S. national park buffer zones: historical, scientific, social and legal aspects. Environ. Manage. 23, 49-173.

Shafer, C.L., 1999b. National park and reserve planning to protect biological diversity: some basic elements. Landscape Urban Plan. 44, 123-1153.

Sinclair, K.E., Hess, G.R., Moorman, C.E., Mason, J.H., 2005. Mammalian nest predators respond to greenway width, landscape context and habitat structure. Landscape Urban Plan. 71, 277-293.

Sodhi, N., 2002. Competition in the air: birds versus aircraft. Auk 119, 587-595.

Solman, V.E.F., 1973. Birds and aircraft. Biol. Conserv. 5, 79-86.

Solman, V.E.F., 1976. Aircraft and birds. Bird Control Sem. Proc. 7, 83-88.

Sterner, R.T., Elias, D.J., Garrison, M.V., Johns, B.E., Kilburn, S.R., 1984. Birds and airport agriculture in the conterminous United States: a review of literature. In: Office of Airport Standards, Wildlife Hazards to Aircraft Conference and Training Workshop, DOT/FAA/AAS, Washington, DC

Stevens, J., 2008. Foraging success of adult and juvenile starlings Sturnus vulgaris: a tentative explanation for the preference of juveniles for cherries. Ibis 127 , 341-347.

Thorpe, J., pp. 85-113 2003. Fatalities and destroyed aircraft due to bird strikes, 1912-2002. In: Proceedings of the 26th International Bird Strike Comm. Meeting, Warsaw, Poland.

Thorpe, J., pp. 17-24 2005. Fatalities and destroyed aircraft due to bird strikes, 2002-2004 (with an appendix of animal strikes). In: Proceedings of the 27th International Bird Strike Comm. Meeting, Athens, Greece.

Tscharntke, T., Klein, A.M., Kruess, A., Steffan-Dewenter, I., Thies, C., 2005. Landscape perspectives on agricultural intensification and biodiversity-ecosystem service management. Ecol. Lett. 8, 857-874.

Tucker, G.M., 1992. Effects of agricultural practices on field use by invertebratefeeding birds in winter. J. Appl. Ecol. 29, 779-790.

Vickery, P.D., Hunter Jr., M.L., Melvin, S.M., 1994. Effects of habitat area on the distribution of grassland birds in Maine. Conserv. Biol. 8, 1087-1097.

Vos, D.K., Ryder, P.A., Graul, W.D., 1985. Response of breeding great blue herons to human disturbance in northcentral Colorado. Col. Waterbirds 8, 13-22.

Vreeker, R., Nijkamp, P., Ter Welle, C., 2002. A multicriteria decision support methodology for evaluating airport expansion plans. Transp. Res. Part D 7, 27-47.

Waller, D.M., Alverson, W.S., 1997. The white-tailed deer: a keystone herbivore. Wildl. Soc. Bull. 25, 217-226.

Washburn, B.E., Seamans, T.W., 2007. Wildlife responses to vegetation height management in cool-season grasslands. Rangel. Ecol. Manage. 60, 319-323.

Washburn, B.E., Barras, S.C., Seamans, T.W., 2007. Foraging preferences of captive Canada geese related to turfgrass mixtures. Human-Wildl. Confl. 1, 188-197.

Weikel, D., 2008, 30 November. John Wayne airport to run with expansion plan. Los Angeles Times, Los Angeles, CA, USA, 30 November. Web site: articles.latimes.com/2008/nov/30/local/me-jwa30.

Wells, M.P., Brandon, K.E., 1993. The principles and practice of buffer zones and local participation in biodiversity conservation. Ambio 22, 157-162.

Wilson, J.D., Morris, A.J., Arroyo, B.E., Clark, S.C., Bradbury, R.B., 1999. A review of the abundance and diversity of invertebrate and plant foods of granivorous birds in northern Europe in relation to agricultural change. Agric. Ecosyst. Environ. 75 13-30.

Wilson, J.D., Taylor, R., Muirhead, L.B., 1996. Field use by farmland birds in winter: an analysis of field type preferences using resampling methods. Bird Study 43, 320-332. 